university as sufficient to qualify a man to present himself for the M.B. examination, nor is the preliminary examination deemed sufficient, while the University of Edinburgh does not even recognise such examination. Moreover, the standard in general edncation required for the M.B. examination is not of itself sufficient for the M.D. degree, and at Edinburgh University the number who graduate to M.D. is only one in four. Dr. Sisley displays a want of knowledge of university regulations and etiquette when he states that a graduate is a "Dr.," while the diplomate is only "Mr." Nobody is entitled to the address of "Dr." by courtesy or otherwise until he has graduated to a doctor's degree in one of the faculties of a university. Bachelors in all faculties are on the same footing in this respect, but the man who is most ready to assume the address of "Dr." is the one with the most inferior diplomas. By all means let us have a teaching university in London, but let it be one which will leave intact the standard of edncation exacted by the presently existing universities. - I am, Sirs, yours truly,

London, Feb. 4th, 1895.

H. Critchlar, M.A. Durh., M.D. Edin.

\section{"AN ATYPICAL ALBINO."}

\section{To the Editors of THE LANCEN.}

SIRS, - So far from nystagmus being an exceptional phenomenon in albinism, as one might infer from Dr. Squire's report of a case in the last issue of THE LANCET, it is, on the contrary, a very usual accompaniment of that condition. The pigmentless condition of the choroid so frequently met with in albinos, and the defective vision consequent thereon, is generally considered to be the canse of this symptom. To my mind, the interest of Dr. Squire's case rests upon the condition of the choroid, and on this point be has not enlightened us; but since he tells us that there seems to be no inconvenience in the presence of a strong light, and no defect of vision (although with regard to the latter I gather we have only the patient's word to guide us ), the inference is that the choroid cannot be very defective. To what, then, is the nystagmus due? In albinism there is generally a total absence ot pigment in the irides, but in blue eyes this is not so, bat merely a deficiercy, a fact which perhaps may account for the unusual amount of vision in this particular case. Considering that the nystagmus is so well marked it would be interesting to know (1) the condition of the choroid, and (2) the visual acuity of the patient.

I am. Sirs, yours faithfully.

R. Bruce Ferguson, M.A., M.B. Cantab.

Feb. 2nd, 1895

\section{"THE DENTIST'S EDCCATION."}

To the Editors of $\mathrm{THE}$ LaNCET.

Sins, - With one point, at least, in Mr. Newland-Pedley's letter in THE LANCET of Feb. 2nd I most cordially agreeviz., that the Royal College of Surgeons should hold an examination in dental mechanies which all dental students should be compelled to pass before entering a hospital for their farther training for the L.D.S. This previous examivation in dental mechanics would ensure the due attention of stadents to this important subject, and would compel practitioners receiving pupils to see that the instruction which they profess to give becomes a fact instead of fiction. ana in the event of their neglect it would be known with whorn the responsibijity rested. At the present timestuder ts may be rejected at the end of their hospital career because that which they should have learnt before they joined a hospital at all was never taught them, and the hospital becomes discredited unfairly, while it is impossible for parents to know with whom the responsibility really lies.

I am, Sirs, yours faithfully,

Storer BenNeTt, F.R.C.S. EnG., L.D.S., \&O. London, Feb. 5th, 1895.

\section{CORONERS AND THEIR DUTIES.}

To the Eaitor of THE LANCET.

SIRS, - You will greatly oblige by giving your opinions concerning the daty of a coroner in the following case. A short time ago I was asked by a midwife (unregistered), who attended the woman in her confinement, to see the body of a child which she said was stillborn. I examined the body, but refused to give a certificate of stillbirth as the child was fully developed and there were no signs that it was born dead. The midwife informed me that the child was bors "feet first." I communicated with the police, telling them that I could not certify and that probably the child diect during the process of birth, and in my opinion if a medicas man had been present the child's life would have been saved, This was reported to the coroner, who gave an order for burial, saying an inquest was unnecessary.

Feb. 4th, 1895.

I am, Sirs, yours faithfully,

\section{THE REMUNERATION OF TIIE RESIDEN? OFFICERS IN ST. BARTHULOMEW'S HOSPITAL. \\ To the Editors of The LAvcers.}

SIRS, - I have heard that within the past few months the governing body of University College Hospital have decided to board as well as lodge the resident house surgeons anction physicians of that institution, and no longer to exact $a_{\text {. }}$ weekly payment from them. I am under the impression that St. Bartholomew's is now the only hospital in London (and, I suppose, it is admittedly the most wealthy) where the resident staff have to board thernselves. I am informed that, although a house surgeon there is paid at the rate of $£ 25$ per annum for his services, yet during the six months in which he is in residence he is usually about $£ 1$ per week. out of pocket for his board. If this be true, is it not a shame that these gentlemen, who give their time and very ofter. their health, and without whose services the work of the hospital could not possibly be carried on, should be subjected to a system of what is little else than sweating? It seems. to me a great pity that the governors of that institutior have allowed smaller institutions, which are dependent on: voluntary contributions, to be before them in making such $c$ : laudable reform in the remuneration of their officials.

Jan. 10th, 1895. I am, Sirs, yours faithfully, FAIR PAY

\section{MANCHESTER.}

(Frow OUR OWN CORRESPONDENT.)

\section{Paupers' Food.}

THE article in the City Ners of the 19th ult. has not beess unnoticed. At the Prestwich Board one of the guardians said the worst day in the table was taken; but even then the cost should have been $3 d$. instead of $1 \frac{1}{2} d$., which would gire. 1s. 9d. for the week; and he stated further that the cost "solely for food and drink" was $2 s .3 d$. In a letter to the paper Dr. Boddy, the medical officer to the workhouse, states. that the books showed the cost per head was over 23 . a. week, but that the number of young children who consume and receive less food than the adults, with also. some infants at the breast, make the average cost for adults not much less than $2 s .6 d . ;$ and that the fact that the food is bought wholesale makes its amountr. considerably more than if it were bought at retail prices. Moreover, three ounces of tea instead of one and a quarter ounces are used to fourteen pints of water, and no soda $i s$ added. Pea-soup is given twice a week, and it is said not to be thin, but good. On four days meat and potatoes, and or: Sundays bacon, potatoes, and bread, are given; and a few: years ago new milk was substituted for skim milk. At the: Salford Board the chairman of the workhouse visiting com. mittee maintained that "margarine was better than kac" butter," and that it cost more than $6 a$. a pound. There was some difference of opinion as to the tea, the chairman saying. it Was good enough for him, and that the old people preferred it without milk. Another of the guardians took a more generous view : "It was no use saying the tea was good" with eight pints of water to an ounce of tea, and be would reduce the water to six pints. Indeed, he considered that the paupers should be treated "like ordinary Christians," and should have milk in their tea. The recent circular of the poor law board is so humane and considerate in tone that it seems as if for the sick and aged the days of penal severit may come to an end as soon as the guardians, or at least some of them, have grasped the idea that old age and sick ness are not criminal.

Medico-Ethical Association and the Midroives' Diplomes. A special meeting of this association was held about ter. 